\title{
DÉL-DUNÁNTÚL AGRÁRGAZDASÁGÁNAK HELYZETKÉPE, LEHETŐSÉGEI ${ }^{34}$
}

\author{
Weber Erika ${ }^{1}$

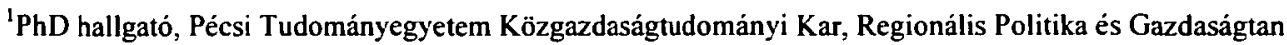 \\ Doktori Iskola, Pécs
}

\section{SUMMARY}

Basis of my research is the Southern Transdanubian Region. The statistical analysis showed that output, commensurable to the region's territory, can be performed only by the agricultural production. The Southern Transdanubia is the most important producer of corn and cereals, as well as in growth of sugar beet and soya in the country, and it has prominent role in growth of sunflower and rape, as well as in producing qualitative red wine. The significance of the agricultural sector is shown by the fact that despite the decrease of the food sector's importance, the food industry is the largest sector beside the energetics industry in the region. However, the competitiveness of the sector is not adequate, increase of which is essential from the aspect of the industry. One of the instruments is integration of the small growers.

Kulcsszavak: Dél-Dunántúli régió, agrárgazdaság, versenyképesség, hatékonyság, integráció

\section{BEVEZETÉS}

TÁMOP kutatásunk a Dél-Dunántúl gazdasági erőforrásainak feltárására irányul, amelynek lényeges területét képezi az agrárgazdaság helyzete, versenyképessége. A régió gazdasági helyzetét jól tükrözi, hogy gazdasági teljesítménye alapján az Európai Unió utolsó 20 legkisebb teljesítményt nyújtó régiói között szerepel. A területével arányos teljesítményt csak az agrártermelés tud felmutatni. A kutatás első részeként egy helyzetfelmérést készitettünk, mely során a régió agrárpotenciálját is külön felmértük. Az agrárágazat jelentőségét az is mutatja, hogy több élelmiszeripari ágazat leépülése ellenére az élelmiszeripar az energetikai ipar mellett a régió legjelentősebb iparága. Az ágazat versenyképessége azonban nem megfelelő, ennek növelése létkérdés az ágazat szempontjából. A kutatás eredményeiből is kitünik, hogy az agrárpotenciál gyengén kihasznált, ami a gazdaságszerkezetnek és a hiányos gazdaságpolitikai fejlesztéseknek köszönhetö. A továbbiakban a meglévő erőforrások hatékonyságának növelését segitő eszközök, folyamatok feltárása a célunk. A hatékonysághoz, versenyképesség növeléshez vezető egyik fontos eszköz lehet például a kistermelök integrálása.

\section{A DÉL-DUNÁNTÚLI RÉGIÓ GAZDASÁGSZERKEZETE}

Magyarországon a rendszerváltás után meghatározó folyamat volt a nagygazdaságok felaprózódása, ami az elmúlt évtizedben is folytatódott mind országosan, mind a DélDunántúlon. Ezzel egyidejüleg azonban az egyéni gazdaságok száma is nagymértékben csökkent, így a gazdaságok száma összességében jelentősen lecsökkent, de nemzetközi összehasonlításban még mindig rendkívül nagy. A gazdaságok számának változása a DélDunántúli régióban is követte az országos tendenciákat. Az országos változásokhoz viszonyítva a társas vállalkozások száma kisebb mértékben növekedett, míg az egyéni gazdaságok csökkenése jelentősebb volt annál. Egymáshoz viszonyítva a társas vállalkozások

\footnotetext{
${ }^{34}$ A tanulmány a TÁMOP-4.2.1. B-10/2/KONV-2010-0002, A Dél-Dunántúli régió egyetemi versenyképességének fejlesztése projekt, Dél-Dunántúl gazdasági erőforrásainak feltárása és fejlesztési lehetőségek meghatározása c. alprojekt keretében készült. Kutatás vezetője: dr. Buday-Sántha Attila
} 
növekedése kisebb mértékü volt, mint az egyéni gazdaságok csökkenése, így nem volt képes ellensúlyozni azt, aminek következtében az összes vállalkozás száma is nagyobb mértékben csökkent, mint országos szinten a vállalkozások száma. (1. táblázat) Az egy évtized alatti csökkenés arra utal, hogy egy eröteljes koncentrációs folyamat indult be az agrártermelésében. (Buday-Sántha A. 2011)

\section{3. táblázat: Regisztrált vállalkozások száma a mezõ- és erdőgazdaságban}

\begin{tabular}{|c|c|c|c|c|c|c|c|c|c|}
\hline \multirow[b]{2}{*}{ Megnevezés } & \multicolumn{3}{|c|}{ Társas vállalkozás } & \multicolumn{3}{|c|}{ Egyéni vállalkozás } & \multicolumn{3}{|c|}{ Összesen } \\
\hline & 2000 & 2010 & $\begin{array}{c}2010 \\
2000 \\
\% \text {-ában }\end{array}$ & 2000 & 2010 & $\begin{array}{c}2010 \\
2000 \\
\% \text {-ában }\end{array}$ & 2000 & 2010 & $\begin{array}{c}2010 \\
2000 \\
\% \text {-ában }\end{array}$ \\
\hline Magyarország & 8382 & 13444 & $160 \%$ & 958534 & 405897 & $42 \%$ & 966916 & 420179 & $43 \%$ \\
\hline Dél-Dunántúl & 1417 & 1999 & $141 \%$ & 122824 & 41534 & $34 \%$ & 124241 & 43533 & $35 \%$ \\
\hline Baranya megye & 470 & 758 & $161 \%$ & 37714 & 12372 & $33 \%$ & 38184 & 13130 & $34 \%$ \\
\hline Somogy megye & 623 & 794 & $127 \%$ & 52389 & 17586 & $34 \%$ & 53012 & 18380 & $35 \%$ \\
\hline Tolna megye & 324 & 447 & $138 \%$ & 32721 & 11576 & $35 \%$ & 33045 & 12023 & $36 \%$ \\
\hline
\end{tabular}

Forrás: Általános mezőgazdasági összeírás adatai és KSH Évkönyvek $(2000,2010)$ alapján saját szerkesztés, 2011

A rendszerváltás után a mezőgazdaság válsága a földterületet is érintette. Az épitett környezet számára, fejlesztésekre, útépítésekre a föld minőségétől, agrárértékétöl függetlenül szinte korlátlanul vontak ki földterületeket a termelésből. A müvelési ágak közül leglátványosabban a szölö- és gyepterületek nagyságát érintette a terület csökkenés. A fokozatos állatállomány csökkenés és az ennek köszönhető takarmányszükséglet mérséklödése is nagy hatással volt a termőterületek változására. A múvelési ágak közül csupán az erdö és halastavak területénél érzékelhető növekedés. (2. táblázat) A szántóterületek csökkenése, föként az Európai Uniós támogatásoknak és a gyepterületek egy részének szántóföldi müvelésbe vonása következtében kisebb ütemü volt a termőterület csökkenéséhez viszonyítva. A kivont területek egy része azonban így is a legjobb termöképességü területekröl történt. (Buday-Sántha A. 2011)

\section{4. táblázat: Mũvelési ágak szerkezete (\%)}

\begin{tabular}{|c|c|c|c|c|c|c|c|c|c|c|c|c|}
\hline & Szántó & Kert & Gyümölesōs & Szzõlõ & Gyep & $\begin{array}{c}\text { Mg-i } \\
\text { terület }\end{array}$ & Endõ & Nádas & Halasto & $\begin{array}{l}\text { Termö- } \\
\text { terület }\end{array}$ & $\begin{array}{c}\text { Múvelés } \\
\text { alól } \\
\text { kivont }\end{array}$ & Összesen \\
\hline \multicolumn{13}{|c|}{ Magya rország } \\
\hline 1990 & 50,7 & 3,7 & 1,0 & 1,5 & 12,7 & 69,6 & 18,2 & 0,4 & 0,3 & 88,5 & 11,5 & 100,0 \\
\hline 2010 & 48,4 & 1,0 & 1,0 & 0,9 & 8,2 & 59,5 & 20,6 & 0,7 & 0,4 & 81,2 & 18,8 & 100,0 \\
\hline \multicolumn{13}{|c|}{ Dél-Dunántúl } \\
\hline 1990 & 50,8 & 4,1 & 0,5 & 1,3 & 9,3 & 66 & 22,7 & & & 88,5 & 11,5 & 100,0 \\
\hline 2010 & 51,7 & 0,7 & 0,4 & 1,0 & 5,2 & 59 & 26,2 & 0,6 & 0,4 & 86,2 & 13,8 & 100,0 \\
\hline
\end{tabular}

Forrás: KSH évkönyvek adatai alapján saját szerkesztés, 2011

\subsection{A DÉL-DUNÁNTÚL TERÜLETÉNEK HASZNOSÍTÁSA}

A régió vetésszerkezetét alapvetően a gabonafélék és olajos magvak túlsúlya jellemzi, a térség tehát az ország kiemelt gabonatermesztési régiója. Ez elsősorban a kukorica- és búzatermesztésnek köszönhető. Gabonatermesztésben a régió meghatározó szerepe az 
országos átlagot meghaladó termésátlagoknak is köszönhetö. Szerepe az olajosmagtermesztésben is rendkívül fontos, különösen a repcetermesztés aránya a meghatározó, de a napraforgó is átlagon felüli termésátlaggal termelhető. A régió agrárgazdasági jelentőségét az is bizonyítja, hogy a kedvező termelési adottságok miatt a térségben szinte minden növény eredményesen termelhetõ. A régió zöldség termelése azonban a többi termesztett növényhez képest az ország termelésében nem meghatározó, a termőterület és a hozam csökkenése folyamatos. Gyümölcstermelésben is az országos értékhez hasonlóan a régió termőterülete is folyamatosan csökken és a szölö- és bortermelés is csökkenő tendenciát mutat, bár ez a folyamat a Villányi borvidéket nem érintette. (Buday-Sántha A. 2011)

A vizsgált időszakban a növénytermesztéshez hasonló jelentős változások következtek be az állattenyésztésben is. A régióban föként szarvasmarha, sertés, juh, baromfitenyésztéssel foglalkoznak.

Magyarország szarvasmarha-állománya a rendszerváltás óta folyamatosan csökken, azonban az állomány változása az ország egyes régióiban eltérő módon ment végbe. A DélDunántúli régió szarvasmarha állományának csökkenése meghaladta az országos átlagot. Hasonló tendenciák jellemzik a tehénállomány alakulását is. 1990 után az ország sertéslétszáma is radikálisan lecsökkent. A kocalétszám csökkenése a vizsgált időszakban még nagyobb mértékü volt. A juhállomány esetében eltérö tendencia figyelhetö meg. A rendszerváltás után az állomány jelentösen csökkent, azonban 2005-re növekedés figyelhető meg, ami azonban nem volt tartható, és 2010-re ismét lecsökkent a juhállomány mind a DélDunántúlon, mind az országban, ez szintén az Európai Uniós támogatási rendszernek és kvótáknak köszönhető. A baromfifélék esetében is csökkenés figyelhető meg az állomány tekintetében, azonban a többi állatfajhoz képest a baromfiak esetében volt a legkisebb mértékü a változás. 2010-re a rendszerváltás kori állomány 76,5\%-át (3. táblázat) tudta tartani a régió. Összefoglalóan a rendszerváltást követően a Dél-Dunántúli régió gazdasági állatállománya 2010-ig az országos átlagot is meghaladó mértékben csökkent. (Buday-Sántha A. 2011)

5. táblázat: Állatállomány alakulása (ezer darab)

\begin{tabular}{|c|c|c|c|c|c|c|c|}
\hline \multicolumn{2}{|c|}{ Megnevezés } & 1991 & 2000 & 2005 & 2010 & $\begin{array}{l}2010 a \\
1991 \%-\end{array}$ & $\begin{array}{c}2010 \text { a } \\
2000 \%-\end{array}$ \\
\hline \multirow{2}{*}{$\begin{array}{c}\text { szarvas marha } \\
\text { állomány }\end{array}$} & Magyarország & 1420 & 805 & 708 & 682 & 48 & 84,7 \\
\hline & DérDunántúl & 201 & 105 & 87 & 71 & 35,3 & 67,6 \\
\hline \multirow{2}{*}{ te hé nlé ts zám } & Magyarorsźg & 559 & 380 & 334 & 309 & 55,3 & 81,3 \\
\hline & Dér-Dunántuil & 76 & 48 & 41 & 33 & 43,4 & 69,8 \\
\hline \multirow{2}{*}{$\begin{array}{c}\text { sertés } \\
\text { állomány }\end{array}$} & Magyarorszag & 5993 & 4834 & 3853 & 3169 & 52,9 & 65,6 \\
\hline & Dér-Dunántúl & 936 & 837 & 718 & 536 & 57,3 & 64 \\
\hline \multirow{2}{*}{ kocalétszám } & Magyarország & 482 & 348 & 277 & 219 & 45,4 & 62,9 \\
\hline & Dér-Dunántúl & 80 & 61 & 48 & 36 & 45 & 59 \\
\hline \multirow{2}{*}{ juhállomány } & Magyarország & 1808 & 1129 & 1405 & 1181 & 65,3 & 104,6 \\
\hline & Dér-Dunántúl & 144 & 93 & 124 & 94 & 65,3 & 101 \\
\hline \multirow{2}{*}{$\begin{array}{l}\text { baromfi } \\
\text { állomány }\end{array}$} & Magyarország & 35557 & 30716 & 31902 & 31848 & 89,6 & 103,7 \\
\hline & Dér-Dunántúl & 4291 & 4149 & 3770 & 3174 & 74 & 76,5 \\
\hline
\end{tabular}

Forrás: KSH évkönyvek adatai alapján saját szerkesztés, 2011 
A növénytermesztés és állattenyésztés mellett az erdőgazdálkodás is fontos ágazat a régió szempontjából. A vizsgált időszakban az erdögazdálkodásba vont területek folyamatos növekedése figyelhető meg. Az erdősités ütemét az erdősítéshez megszabott állami támogatás alacsony kerete korlátozza. Az erdögazdálkodásnak nagy szerepe van a régió, döntöen Baranya megye esetében az energiaellátásban.

\section{2. ÉLELMISZERIPAR}

A feldolgozó ipar ágazati mutatói sokkal vegyesebb képet mutatnak a régióról. Az értékesités elsősorban a hazai piacokon történik, csupán Baranya esetében magas, egyharmad az export aránya, mely föként a dohánynak köszönhető, Somogy megye esetén ez arány $20 \%$, Tolna megyében mindössze alig 6\%. Tehát értékében és arányaiban is Baranya megye a legnagyobb exportőr a régióban az élelmiszer, ital és dohánytermékek esetén. (4. táblázat) Baranya megye áll az első helyen a teljes munkaidőben foglalkoztatottak száma tekintetében is. A termelékenységi mutató alapján pedig Somogy megye emelkedik ki.

2010-ben a HVG által kiadott lista alapján a 20 legnagyobb árbevétellel rendelkezỏ Déldunántúli vállalkozások közül 12 a feldolgozóiparhoz, illetve az agrárkereskedelemhez köthető. Ágazatok szerinti bontásban az élelmiszer, ital és dohánytermékkel kapcsolatos vállalkozások a legjelentősebbek, a 12 vállalkozás közül 6 (British American Tobacco Magyarország Kft., BAT Pécsi Dohánygyár Kft. (már csak telephellyel), Mecsek Füszért Zrt., Kometa 99 Zrt., Tejinvest Kft., Tolnatej Zrt., Sió Eckes Kft.) ezt az ágazatot érinti.

\section{6. táblázat: Az élelmiszeripar jellemzői Dél-Dunántúlon (2010)}

\begin{tabular}{|l|ccc|c|}
\hline \multicolumn{1}{|c|}{ Megnevezés } & Baranya & Somogy & Tolna & Dél-Dunántú \\
\hline Ipa ri temne lés értéke (millió Ft) & 32485 & 41465 & 26728 & 100678 \\
Értékesítés belföldön (millió Ft) & 22242 & 33062 & 24834 & 80138 \\
Export értékesítés (millió Ft) & 10855 & 8355 & 1769 & 20979 \\
$\begin{array}{l}\text { Foglalkoztatás teljes } \\
\text { munkaidőben (fó) }\end{array}$ & 3097 & 2317 & 1571 & 6985 \\
Termelékenység (fó/millió Ft) & 10,49 & 17,90 & 17,01 & 14,41 \\
\hline
\end{tabular}

Forrás: KSH adatok alapján saját szerkesztés, 2012

\section{VERSENYKÉPESSÉGET, HATÉKONYSÁGOT NÖVELŐ LEHETŐSÉGEK}

A fenti leírásból is jól látható, hogy a magyar mezőgazdaságra jellemző földtulajdon rendkivüli elaprózottsága a Dél-Dunántúli régió esetében is érzékelhetö. A termöterületek folyamatos csökkenése figyelhető meg, ami a termelök, mezőgazdasági vállalkozók lehetöségeit is jelentősen befolyásolja. Az állatállomány csökkenése is jelentős, de legnagyobb hatása véleményem szerint mindenképpen a termöterület csökkenésének van. A kis területeken folyó termelés hatékonysága eröteljesen megkérdőjelezhető, a termelésböl származó jövedelem nem elegendő az eszközök fejlesztésére, megvásárlására. A földterületek tulajdonosainak azonban nem minden esetben van lehetősége a földjei eladására, mert más megoldás nem is áll elöttük, hogy a megélhetéshez szükséges jövedelmet megszerezzék. A rendszerváltás után a kárpótlási törvények, privatizáció hatására sok esetben nem a hozzáértő szakemberek, szakmunkások tulajdonába kerültek a földterületek, így a gazdálkodók nagy részére jellemző a korszerü termeléshez szükséges szakértelem hiánya. Mindemellett nagy gondot okoz, hogy az egész régiót jelentős tőkehiảny jellemzi, nem csak az agrárágazatot. 
A külföldi tỏke beáramlásának köszönhetően egyre jobban elterjednek a multinacionális kereskedelmi hálózatok, melynek hatására az értékesítési csatornák egyre koncentráltabbak, ami a helyi termelök helyzetét jelentősen megneheziti. A termelök egyre kiszolgáltatottabbak, emiatt egyre nagyobb hangsúlyt kellene fektetni az együttműködésekre. (Tátrai A. 2003) A termékek értékesítésére szinte nincs lehetőségük, a még meglévő piacokon, vásárokon a bérleti dijak mértéke nem teszi lehetővé a megélhetéshez szükséges jövedelemszerzést. Ezen a különböző együttmüködések, integrációk nagyban segíthetnek, mert míg a kis területen megtermelt termékeket önállóan nem tudják értékesíteni, addig több termelö összefogásával már meghatározó mennyiségü termékkel léphet piacra egy ilyen szervezödés.

A termelök döntését az együttmüködések, koordinációk esetében a költségeik alapján határozzák meg. A költségek csökkentése mellett az együttmüködések, integrációk létrehozásának különböző okai lehetnek:

- új piacok szerzése és megtartása,

- a piaci kockázat csökkentése,

- nagyobb hozzáadott értékü tevékenység végzése,

- nagyobb hatás elérése a piacra és az árakra vonatkozóan. (Villányi et. al. 2007)

A vertikális integráció egyik leggyakoribb fajtája a szövetkezet, mely a rendszerváltás elött domináns alkotóelem volt a mezőgazdasági rendszernek hazánkban. A rendszerváltást követően a szövetkezetek átalakulását, felbomlását törvényi előírások szabályozták, amelyek megvalósítása során a kárpótlások, privatizáció káros hatásai jelentkeztek. A mezőgazdasági tulajdon- és birtokszerkezet teljesen átalakult. Ebböl kifolyólag olyan méretü egyéni gazdaságok jöttek létre, melyek, mint ahogy már emlitettem, nem voltak önállóan versenyképesek. Azonban a gazdaságpolitika által támogatott egyéni gazdálkodás egyre nagyobb teret nyert, ezért egyre inkább elötérbe került a termelöi kiszolgáltatottság mérséklése. Az ezredfordulót követöen Magyarországon a mezögazdaságban müködő termelöi szerveződéseknek formájukat, elnevezésüket tekintve egyaránt sokszínủ rendszere alakult ki. Ezekre a termelöi összefogásokra Magyarországon azonban az volt jellemző, hogy a szövetkezések célja elsősorban nem magára az együttmüködésre irányult, hanem a rendelkezésre álló állami támogatások megszerzésére. Megkezdödtek ugyan a kistermelökre irányuló szerveződések is, azonban ezek lassan és kis mértékben jelentkeztek, ami abból a szempontból a leghátrányosabb, hogy a kistermelők, vállalkozók esetben fontos, hogy lássanak egy jól müködö együttmüködést, mely ösztönzöen hathat rájuk és ezek elenyésző száma erre nem adott lehetöséget. (Villányi et. al. 2007)

A szövetkezetek, termelői szerveződések alakulásakor az elsődleges cél az elszigetelt termelök/gazdálkodók összefogásának elösegítése a beszerzés, és a piacon való közös értékesités tekintetében. Ezeket az összefogásokat más szóval horizontális integrációnak nevezi a szakirodalom. Az integráció vertikálisan is kiterjedt, nem csak horizontálisan. Ennek következtében egy-egy ágazat teljes termékpályáját átfogó szövetkezeti rendszer is kialakulhat. Ebben az esetben például vágóhíd, sőt végterméket elöállító feldolgozó üzem is a szövetkezet tulajdonában lehet. (Villányi et. al. 2007) Ezek létesítésével a termelők helyzetét nagyban javíthatják, azonban jelentős hatása lehet magára az ágazatra is, mind a foglalkoztatás, mind a termelés szempontjából. A Dél-Dunántúli régió esetében is egy előrelépést jelenthet ilyen együttmüködési formák megteremtése.

\subsection{INTEGRÁCIÓ A GYAKORLATBAN}

Kiváló példa a fentiekre egy Tolna megyében, Kisvejkén a korábbi termelőszövetkezet területén megalakult együttmüködés, mely szövetkezeti formában valósult meg. Ebben az integrációban a gyümölcstermesztés mára sok ember jövedelem kiegészítését vagy megélhetését szolgálja. 1995-ben végleg megszűnt a korábban müködő szövetkezet, a földek kiosztása is megkezdödött, a tagok jelentős része csak 0,5-2 hektáros földet kapott. (Németh 
et. al. 2010) Ez a folyamat volt jellemző az ország egészében és a régióban is. Müvelési ágaktól függően eltérő, de minden esetben kisméretű földterületekhez jutottak a volt tagok.

Ezek a földterületek nem tüntek gazdaságilag életképesnek, ezért sokan eladták területeiket. Azonban időben felismerték a térségben, hogy a korábbi szövetkezetek felbomlása után a termelés rendszere összeomlott, nem maradt semmi, részben ennek köszönhetően indult el az ,amerikai program”, melyből a Helyi Gazdasági és Vállalkozási Kezdeményezés érintette a térséget. Ennek célja, hogy a helyi problémák megoldásáért, a helyi fejlödésért tenni tudó helyi szereplők együttmüködését, önszervezödését ösztönözze. 1997-ben hét gazda már közösen próbált boldogulni, az „amerikai program” hatására pedig hivatalosan is megalakult a Kisvejke Térségi Gyümölcsértékesitő Szövetkezet. A folyamatos telepítések hatására a 60 hektár helyett ma már 400 hektáron gazdálkodnak. A DanubiaFrucht Kisvejke Térségi Gyümölcsértékesítő Szövetkezet sikeres szervezetté vált. (Németh et. al. 2010)

Kérdés azonban, hogy ez mennyire adaptálható más térségekben, vagy esetleg más mủvelési ágak esetében. Egy ilyen szövetkezeti forma bárhol megvalósítható, azonban mindenhol nagy szerepe van a helyi sajátosságoknak. Kisvejkének nagy előnye volt a korábbi szövetkezeten alapuló hagyományok miatt. A sikerhez azonban szükség volt a vezetök és a gazdák modern szemléletére, hozzáállására is. Fontos azt is figyelembe venni, hogy bár megélhetést biztosít a gazdák számára, azonban ha nem rendelkezik olyan múlttal egy térség, mint Kisvejke, ahol adott volt a korábbi gyümölcsös alapként, a telepítés költségesebb, és az értékesítés megszervezése is fontos feladat. Legmegfelelőbben ott lehet felhasználni ezt a példát, ahol megvan a termelési alap egy ilyen szövetkezet létrehozásához. Le lehet másolni a fejlesztéseket, azonban nem feltétlen hoz majd hasonló eredményt. Mindenhol meg kell találni a helyi sajátosságokban rejlö lehetöségeket. (Németh et. al. 2010)

A Dél-Dunántúli régió esetében egyéb hasonló kezdeményezésekre is van példa. Pécs és térsége esetében szintén a mezőgazdasági kistermelöket célzó integrációra törekednek. A helyi termékekre épülö vendéglátás kialakítására törekednek a „Pécsi Ízek” program keretében például, ami a kistermelöknek lehetőséget nyújt az értékesítés hatékonyságának, sikerességének növelésére. A közétkeztetések esetében egyre nagyobb százalékban a helyi termékek felhasználását írják elő, ami hasonló eredményekhez vezethet majd. Ehhez azonban szintén szükség lenne egy, a kisvejkeihez hasonló tárolási, hütési és leginkább minőségbiztosítási rendszer kialakítására, mely garantálhatná a részt vevő termelők termékeinek minőségét.

\section{4. ÖSSZEFOGLALÁS/KÖVETKEZTETÉSEK}

A Dél-Dunántúli régió az ország (fél)perifériáján fekvő régiója, az Unió egyik legfejletlenebb régiója. A régió célja, az ott élök életkörülményeinek javítását szem elött tartva elörelépni és a versenyképességét fokozni. Komoly történelmi háttérrel rendelkezik a helyi és regionális agrárgazdaság. A rendszerváltást követően a korábban meglévő termékpályák nagyrészt felbomlottak, valamint a KGST országok élelmiszerpiacai bezárultak a magyar termékek elött. Ennek következtében az agrártermelés visszaszorult, azonban a területével arányos teljesítményt csak az agrárgazdaság tud felmutatni ma a régióban. Vagyis az agrárgazdasági potenciál a szétaprózott birtokstruktúra ellenére jelentős maradt a térségben.

A '90-es években a mezőgazdasági termelők piaci ereje a területi szétaprózódásnak köszönhetően lecsökkent és a nagy kapacitású forgalmazókkal kerültek szembe. A korábban viszonylag jól müködö integrációk megszüntek és az új kistermelöi kör számára nehéz helyzet alakult ki. A termelök piaci helyzetének javítására az egyik lehetöség az együttmüködés. Az összefogás és együttes piacra lépés csökkentené az aszimmetriát a termelők és a forgalmazók közt. 
A Dél-dunántúli régióban elkezdődtek szövetkezetalapítási kezdeményezések. Ezek közül az egyik leghatékonyabban mủködő a kisvejkei példa, ahol a helyi közösség és termelöi társadalom által szervezödött a Danubia-Frucht Kisvejke Térségi Gyümölcsértékesítő Szövetkezet. Egy ehhez hasonló szövetkezésnek két feltétele van. Az első, hogy a térség sajátossági, hagyományai megfelelő hátteret biztosítsanak a szövetkezésnek. A másik pedig a vállalkozói/termelői társadalom aktív részvétele a kezdettektöl fogva. Mindemellett fontos, hogy egy szakmailag hozzáértő vezetővel rendelkezzen egy ilyen együttmüködés, és a tagok közti bizalom is elengedhetetlen feltétele a müködésnek. A tőkehiány azonban az ilyen kezdeményezéseknek is útjába állhat.

A Dél-Dunántúlon az agrárgazdaság rendkivül fontos lehet az életszínvonal növelésében és összességében a régió elörelenditésében. A piaci és termelési viszonyok megváltozására az együttmüködés és integrációs mechanizmusok megfelelő reakciók lehetnek. Minderre nagy szüksége van a régiónak. Az agrárszektor a GDP termelésben, az életszínvonal növelésében csekély arányban van jelen, azonban a régióban az ipari szektor nagy hiányosságai, és csekély jelenléte megköveteli, hogy nagyobb figyelmet fordítsanak az agrárgazdaságra. A térség ezen a téren jó adottságokkal rendelkezik, melyet ki tud használni a nagyvállalatok megtelepedése nélkül, és alacsonyabb beruházási szint mellett is. Ugyanezen feltételek mellett például az ipari vagy szolgáltatási szektor nem tud, illetve nehezebben tudna fejlödni a régióban, amit igazol a régióban az elmúlt évtizedek folyamán leépülö ipari szektor is.

\section{FELHASZNÁLT IRODALOM}

Buday-Sántha A. (2011): Dél-Dunántúli régió kutatás, TÁMOP - 4.2.1.B - 10/2/KONV 2010-0002, Munkaváltozat, PTE KTK Regionális Politika és Gazdaságtan Doktori Iskola, Pécs.

HVG (2011): Trend: TOP 500, HVG 2011/40, Budapest.

Központi Statisztikai Hivatal (2000): Általános mezőgazdasági összeírás adatai, Központi Statisztikai Hivatal, Budapest.

Központi Statisztikai Hivatal (2010): Általános mezőgazdasági összeírás adatai, Központi Statisztikai Hivatal, Budapest.

Központis Statisztikai Hivatal (1991): Területi Statisztikai Évkönyv, Központi Statisztikai Hivatal, Budapest.

Központis Statisztikai Hivatal (2000): Területi Statisztikai Évkönyv, Központi Statisztikai Hivatal, Budapest.

Központis Statisztikai Hivatal (2005): Területi Statisztikai Évkönyv, Központi Statisztikai Hivatal, Budapest.

Központis Statisztikai Hivatal (2010): Területi Statisztikai Évkönyv, Központi Statisztikai Hivatal, Budapest.

Németh N. - Csite A. - Kabai G. (2010): A szövetkezeti gyümölcstermesztés sikere a Völgységben, A „Helyi Kezdeményezésű Gazdaságfejlesztési Programok Értékelése” című kutatás résztanulmánya, Pannon.Elemző Iroda Kft., Gyulaj.

Tátrai A. (2003): A folyamati (általános, generikus) benchmarking alkalmazása sikeres ipari SCM módszerek átültetésére élelmiszeripari és mezőgazdasági vállalatok gyakorlatába, EU WORKING PAPERS 1/2003, Budapest, pp. 30-39.

Villányi L. - Vasa L. (2007): Agrárgazdaságtan, EU agrár-, és környezetpolitika, Debreceni Egyetem Agrár- és Müszaki Tudományok Centruma Agrárgazdasági és Vidékfejlesztési Kar, Debrecen. 